Scientific Journal of October 6 University

ISSN (Print): 2314-8640

ISSN (Electronic): 2356-8119

Published by October 6 University (C) All Rights Reserved

Available online at: http:// sjou.journals.ekb.eg

Original Article
Citation: Abdel-Maksoud et al., (2016). Biochemical Effect of Emblica Officinalis on Experimentally Induced Tumor in Female Mice Sci. J. of Oct. 6 Univ.3(1), 1-6.

Copyright: (ㅇ 2016 Abdel-Maksoud et al. This is an open-access article distributed under the terms of the Creative Commons Attribution License, which permits unrestricted use, distribution, and reproduction in any medium, provided the original author and source are credited.

\title{
Biochemical Effect of Emblica Officinalis on Experimentally Induced Tumor in Female Mice
}

\section{H.A. Abdel-Maksoud,Y.A. El-Senosi and M.M.A. El-Bialy}

Department of Biochemistry, Faculty of Vet. Med., Benha University, Benha, Egypt.

\section{Received: 15-11-2014/ Revised: 20-11-2014 / Accepted: 25-12-2014}

\begin{abstract}
A total number of 150 Australian female mice, 12-14 weeks-old were used, weighted and classified into two main experimental groups. Non-tumor bearing mice (NTB) included 60 female mice and tumor bearing mice (TB) included 90 female mice, which divided into equal three subgroups (each 20 and 30 female mice for NTB and TB, respectively) to investigate the effect of Emblica Officinalis orally treatment at levels of 0,500 and $1250 \mathrm{mg} / \mathrm{kg}$ body weight every alternate day for 3 weeks on serum enzyme activities (AST and ALT), constituents (bilirubin and creatinine) and antioxidant enzymes activities ( catalase, superoxide dismutase SOD, reduced glutathione GSH). Blood samples were collected from all animals groups after 1, 2 and 3 weeks from treatment. Results revealed significant increases in serum AST, ALT, ALP, bilirubin and creatinine concentrations as a result of Emblica Officinalis treatment in TB group as compared to NTB group (control) .Serum GSH, SOD and catalase activity values were significantly decreased in tumor bearing mice when compared with control. The results of this study indicated that Emblica Officinalis treatment has potential benefits in cancer treatment in female mice.
\end{abstract}

Key Words: Chemoprotective, Emblica officinalis, Tumor and Mice.

\section{Introduction}

Cancer is a disease of misguided cells which have high potential of excess proliferation without apparent relation to the physiological demand of the process. It is the second largest single cause of death in both men and women, claiming over six million lives each year worldwide. In modern medicine, chemotherapy, radiotherapy and surgery are the three major existing modes of treatment ${ }^{(1)}$. Phyllanthus emblica is a medicinal plant belonging to the Euphorbiaceae family, described in Ayurveda and is a constituent of several poly herbal formulations. The fruit is the most commonly used part of this plant and is the richest natural source of vitamin C. Emblica officinals (Amla) is highly nutritious and dietary source of minerals and amino acids. It contains calcium, carbohydrates, fats, gallic acid, glutamic acid, magnesium, protein, sulphur, and tannins. It is used for treating bleeding, hemorrhoids, anemia, diabetes, inflammation, hiccoughs, hepatitis B, conjunctivitis and various other uses. Reported biological activities are anti mutagenic activity, anti carcinogenic activity, anti tumour activity, antimetastatic activity, chemo prevention activity, cytoprotective activity, anti oxidant activity and various other activities ${ }^{(2)}$. Many studies indicate that many plants used by herbal healers have been scientifically shown to possess antiviral, cancer preventive and of therapeutic value $(3,4)$. Accordingly, the purpose of this study was to investigate the effect of orally treatment by Emblica Officinalis on some serum parameters for experimentally induced tumor female mice.

\section{Material and methods \\ Experimental animals:-}

A total number of 150 Australian female albino mice of 12-14 weeks-old were obtained from the research institutes of ophthalmology, Giza, Egypt. Mice were weighted (25-30 g), divided into two main experimental groups. Mice were housed in separate metal cages, fresh and clean drinking water was supplied Ad-libitum through specific nipple. Mice were kept at a constant environmental and nutritional condition throughout the experimental period. 


\section{Experimental design:-}

The first experimental group was nontumor bearing mice" NTB-mice". It was included 60 of female mice which divided into three sub groups, each one consisting of 20 mice, then orally treated with $0.2 \mathrm{ml}$ of normal saline, 500 and $1250 \mathrm{mg}$ Emblica officinalis $/ \mathrm{kg}$ body weight every alternate day for 3 weeks . the second experimental group was tumor bearing mice "TB- mice". It was included 90 of female mice, then ehrlich ascites carcinoma (EAC) cells were aspirated from the tumour bearing mice aseptically, diluted with phosphate buffer saline (PBS) and $2.5 \times 10^{6}$ EAC cell in a $0.3 \mathrm{ml}$ phosphate buffer and injected intraperitoneally (single suspension injection) to obtain ascetic tumor in mice. The tumor developed in all injected animals at 5-7 days post - tumor inoculation. TB-mice were divided into three sub groups, then orally treated with $0.2 \mathrm{ml}$ of normal saline, 500 and $1250 \mathrm{mg}$ Emblica officinalis $/ \mathrm{kg}$ body weight every alternate day for 3 weeks.

\section{Parameters estimated and data collection:-}

Blood samples were collected in the morning after overnight fasting from all mice by decapitation every $1,2,3 \mathrm{wks}$ from the onset of treatment, then obtained in dry and clean tubes and serum was separated by centrifugation at $3000 \mathrm{rpm}$ for 15 minutes. The clear serum was aspirated and received in dry sterile sample tube, processed directly for enzymes determination, then kept in a deep freeze at $-20^{\circ} \mathrm{C}$ until used for subsequent biochemical analysis.

Biochemical analysis: Serum (AST and ALT) activity, bilirubin, creatinine, catalase, superoxide dismutase (SOD) and reduced glutathione (GSH)were analyzed colorimeterically according to the methods described by Reitman and Frankel ${ }^{(5)}$, Walter and Gerarde ${ }^{(6)}$, Rock et al. ${ }^{(7)}, \mathrm{Aebi}^{(8)}$, Beulter et al. ${ }^{(9)}$ and Nishikimi et al ${ }^{(10)}$, respectively.

Statistical analysis: The obtained results were Statistical analysis was done by using Data were analyzed by the analysis of variance according to SAS ${ }^{(11)}$. Significant differences among means were detected by the Duncan's Multiple Range Test ${ }^{(12) .}$

\section{Results and Discussion}

Results in table (1) revealed significant increases in serum (AST and ALT) activities, bilirubin, creatinine and alkaline phosphatase concentration in TB female mice. Meanwhile, significant decreases in serum catalase activity, superoxide dismutase and reduced glutathione were observed in tumor-bearing female mice during the experimental period as compared with control. Similarly, Rafei et al. ${ }^{(13)}$ recorded that a rise in plasma bilirubin and hepatic enzyme activities were observed in tumor bearing rats is the results of changes in the liver indicated by the presence of tumor.
This study examined the effect of Ehrlich ascites carcinoma (EAC) tumor on these liver functions parameters and the effect of Emblica Officinalis (EO) treatment on these parameters in non-tumor bearing and tumor bearing mice. The results showed that serum transaminases (AST and ALT), alkaline phosphatase and bilirubin levels were elevated in tumor-bearing female mice at the different time intervals (1, 2 and 3 weeks after inoculation of ascitic tumour cells) in comparison with non-tumor bearing mice. These findings are in agreement with Salem et al. ${ }^{(14)}$, who reported significant elevations of hepatic enzymes in EAC tumor bearing mice. This could be due to the hepatic damage resulting from tumor cell invasion. Moreover, Tofani et al. ${ }^{(15)}$ indicated that larger tumor masses and the associated liver necrosis are considered as metabolic overload of the liver leading to elevation of liver enzymes. Moreover, EAC caused significant deterioration of liver morphology.

Treatment of non-tumor bearing mice with EO caused no significant changes in AST, ALT, alkaline phosphatase and bilirubin. On the other hand, treatment of tumor-bearing mice caused significant reduction in the activity of liver enzymes (AST, ALT and alkaline phosphatase) and serum bilirubin after 1,2 and 3 weeks of experiment. These findings suggest that EO has hepatoprotective effect in EAC-induced mice. Similar results demonstrated the hepatoprotective effect of EO in other models of hepatic injury ${ }^{(16,}$ 17).

Serum creatinine concentration revealed a very highly significant increase after 1, 2, and 3 weeks of tumor induction in saline treated groups in comparison with their normal group. The observed increase in serum creatinine level in tumor bearing mice are similar to the results of other authors $(18,19)$ who observed that serum creatinine level showed a significant increase in mice-bearing Ehrlich ascites carcinoma. Moreover, the increase in plasma creatinine concentration in tumor bearing mice may attribute to the increase of muscle necrosis Hussein ${ }^{(20)}$. As confirmed observed that, creatinine was decreased in tumor-bearing rats as the glomerular lesions progressed, associated with a rise in serum creatinine level $^{(21)}$. Also, this elevation in serum creatinine could be attributed to tumor cell invasion to kidney tissues.

Serum GSH, SOD and catalase activities revealed a significant decrease in tumor bearing female mice along the periods of experiment in saline-treated group in comparison with its normal control. Similar results were reported by previous studies ${ }^{(22)}$. Moreover, noticed a very large difference in catalase activity among the tissues and cell lines ${ }^{(23)}$. Most neoplastic cell lines were low in catalase activity although some possessed large amounts, like the promyelocytic leukemia cell line HL 60. 
Effect of emblica officinalis on survival rate and percentage:

Tables (3) show the number of survived and dead mice and percentage of survived tumor bearing mice. In each group, we started with 30 mice. In the first group (saline treated), the dead mice was 2 in the first week, 4 in the second week and 6 in the third week. So, the total number of died and survived mice in this group was 12 and 18, respectively. While in the second group (treated with $500 \mathrm{mg} E O / \mathrm{kg}$ ), the dead mice was 1 in the first week, 3 in the second week and 3 in the third week. So, the total number of died and survived mice in this group was 7 and 23, respectively. In the third group (treated with $1250 \mathrm{mg}$ EO $/ \mathrm{kg}$ ) the dead mice was 2 in the second week and 2 in the third week. So, the total number of died and survived mice in this group was 4 and 26, respectively. Generally, the total number of survived mice was 18,23 and 26 mice for EAC mice treated with saline , 500 and $1250 \mathrm{mg}$ EO $/ \mathrm{kg}$, respectively, whereas, the percentage of survived was $60.0,76.66$ and $86.66 \%$ for the same groups, respectively.

\section{Effect of emblica officinals treatment on ascetic} volume and cell count:

Table (4) show the effect of $E O$ treatment with different doses on volume of ascitic fluid. Treatment with $500 \mathrm{mg}$ Emblica officinalis $/ \mathrm{kg}$ had significantly $(\mathrm{p}<0.05)$ attenuated the volume of ascitic fluid at 8, 15 and 23 day after injection when compared to saline treated group, whereas, increasing EO dose up to $1250 \mathrm{mg} / \mathrm{kg} \mathrm{BW}$ resulted in significant attenuation as compared to $500 \mathrm{mg}$ $E O / \mathrm{kg}$ group . Volume of ascitic fluid in T-bearing mice was significantly decreased by $51.87,54.08$ and $80.15 \%$ for the mice treated group with 1250 $\mathrm{mg} E O / \mathrm{kg}$ as compared to those treated with saline at 8,15 and 23 day, respectively. Also, show the effect of $E O$ treatment with different doses on tumor cell count per ml. Tumor cell count per ml was significantly attenuated by treatment with 500 or $1250 \mathrm{mg} \mathrm{EO} / \mathrm{kg}$ at 8,15 and 23 day after the injection when compared to saline treated group. Increasing $E O$ dose up to $1250 \mathrm{mg}$ caused significant attenuation in the tumor cell number as compared to $500 \mathrm{mg} \mathrm{EO} / \mathrm{kg}$ at different times. Tumor cell number per $\mathrm{ml}$ of $\mathrm{T}$-bearing mice was significantly decreased by $40.09,48.04$ and 51.66 $\%$ for the mice treated group with $1250 \mathrm{mg}$ EO $/ \mathrm{kg}$ as compared to those treated with saline at 8,15 and 23 day, respectively.

Recent studies indicate that he immense potential of $E O$ in cancer prevention and treatment. However, gaps in the studies conducted are apparent which need to be bridged for EO to be of regular use in cancer treatment and prevention. Moreover, the mechanism of action of the herbal drugs and their extract preparations differs in many respects from that of synthetic drugs. Also, antioxidant principles showed cytotoxicity towards tumor cells and antitumor activity in experimental animal. So, in this study we investigated the effects of anticancer activity of EO and its effects on some biochemical parameters such as liver enzymes, serum bilirubin, serum creatinine and antioxidants such as GSH, SOD and catalase in normal healthy and EAC tumor mice.

The anticancer potential of EO was assessed by change in number and percentage of survived mice and total volume of ascitic fluid and tumor cell count parameters. The Emblica officinalis treated animals at doses of $500 \mathrm{mg}$ and $1250 \mathrm{mg} / \mathrm{kg}$ body weight showed significant reduction in the tumor volume and tumor cell count, and also prolongation in survival time and increase in number and percentage of survived animals in a dose dependent manner when compared with EAC tumour bearing mice. These findings are in agreement with those obtained by Lemma (2011) who reported significant prolongation in survival time of EAC-mice treated with Terminalia Chebula, Terminalia Bellerica and Phyllanthus Emblica.

The ascitic fluid is the direct nutritional source for tumor cells, and the faster increase in ascitic fluid with tumor growth could possibly be a means to meet the nutritional requirements of tumor cells. The reliable criteria for judging the value of any anticancer drug are the prolongation of lifespan of the animal and control of tumour growth and size. Emblica officinalis decreased the ascitic fluid volume, and thereby decreasing the nutritional fluid volume and arresting the tumor growth, so it increased the number of survived EAC-bearing mice. Table no. 4 depicts the beneficial effect of $E O$ on the number and percentage of survived of EACbearing mice. In the EAC- saline treated mice, the number of survived mice was 18 mice out of 30 $(60 \%)$ which increased to 23 of $30(76.66 \%)$ with EO at a dose of $500 \mathrm{mg} / \mathrm{kg}$ and to 26 of 30 $(86.66 \%)$ with EO at a dose of $1250 \mathrm{mg} / \mathrm{kg}$. A regular rapid increase in ascitic tumour volume was noted in tumour bearing mice. The increase in percentage of survived mice of tumor-bearing mice by the treatment is a positive result and supports the anti-cancer effect of $E O$.

\section{Conclusion and recommendation}

Emblica officinalis has a potent chemopreventive activity against a wide variety of tumors and has great potential in the prevention and treatment of cancer in female mice. In addition, EO exerts chemopreventative activity against cancer due to its content of polyphenols and vitamin $\mathrm{C}$ which has antioxidant and free radicals scavenging activity and trapping of activated metabolites of carcinogen. So we recommend using EO in our food as aprophylactic and preventive for many diseases. 
Conflict of Interest Statement: The author declares no conflicts of interest.

Table 1. Effect of orally Emblica officinalis treatment on blood and serum parameters for non tumor bearing (NTB) and tumor bearing mice (TB) control groups at different periods after treatment.

\begin{tabular}{|c|c|c|c|c|c|c|}
\hline \multirow[t]{2}{*}{ Parameters } & \multicolumn{2}{|c|}{1 weeks } & \multicolumn{2}{|c|}{2 weeks } & \multicolumn{2}{|c|}{3 weeks } \\
\hline & NTB & TBM & NTB & TBM & NTB & TBM \\
\hline $\begin{array}{c}\text { AST } \\
(\mathbf{U} / \mathbf{m l})\end{array}$ & $28.10 \pm 3.71$ & $\begin{array}{c}211.27 \pm \\
5.58\end{array}$ & $\begin{array}{c}28.53 \pm \\
4.05\end{array}$ & $\begin{array}{c}264.67 \pm \\
4.60\end{array}$ & $\begin{array}{c}28.83 \pm \\
4.07\end{array}$ & $\begin{array}{c}354.77 \pm \\
12.58\end{array}$ \\
\hline $\begin{array}{l}\text { ALT } \\
(\mathbf{U} / \mathbf{m l})\end{array}$ & $35.83 \pm 3.39$ & $\begin{array}{l}257 \pm \\
12.25\end{array}$ & $\begin{array}{c}35.67 \pm \\
3.78\end{array}$ & $\begin{array}{c}348.33 \pm \\
7.21\end{array}$ & $\begin{array}{c}36.33 \pm \\
4.29\end{array}$ & $\begin{array}{c}531.17 \pm \\
17.30\end{array}$ \\
\hline $\begin{array}{l}\text { Bilirubin } \\
\text { (mg/dl) }\end{array}$ & $0.72 \pm 0.04$ & $\begin{array}{l}2.58 \pm \\
0.03\end{array}$ & $\begin{array}{l}0.71 \pm \\
0.05\end{array}$ & $\begin{array}{c}2.30 \pm \\
0.04\end{array}$ & $\begin{array}{c}0.72 \pm \\
0.04\end{array}$ & $\begin{array}{c}2.00 \pm \\
0.06\end{array}$ \\
\hline $\begin{array}{c}\text { Creatinine } \\
\text { concentrtion } \\
(\mathbf{m g} / \mathbf{d l})\end{array}$ & $0.59 \pm 0.02$ & $\begin{array}{c}2.32 \pm \\
0.86\end{array}$ & $\begin{array}{c}0.63 \pm \\
0.04\end{array}$ & $\begin{array}{c}2.78 \pm \\
0.28\end{array}$ & $\begin{array}{c}0.67 \pm \\
0.04\end{array}$ & $\begin{array}{c}2.98 \pm \\
0.52\end{array}$ \\
\hline $\begin{array}{c}\text { Alkaline } \\
\text { phosphatase } \\
\text { (U/ml) }\end{array}$ & $15.05 \pm 0.66$ & $\begin{array}{c}58.98 \pm \\
0.76\end{array}$ & $\begin{array}{c}14.58 \pm \\
0.64\end{array}$ & $\begin{array}{c}54.53 \pm \\
1.17\end{array}$ & $\begin{array}{c}14.70 \pm \\
0.72\end{array}$ & $\begin{array}{c}47.86 \pm \\
2.259\end{array}$ \\
\hline $\begin{array}{c}\text { Catalase activity } \\
(\mathrm{U} / \mathrm{ml})\end{array}$ & $0.86 \pm 0.007$ & $\begin{array}{l}0.65 \pm \\
0.026\end{array}$ & $\begin{array}{l}0.85 \pm \\
0.012\end{array}$ & $\begin{array}{l}0.44 \pm \\
0.008\end{array}$ & $\begin{array}{c}0.85 \pm 0.00 \\
7\end{array}$ & $\begin{array}{l}0.17 \pm \\
0.014\end{array}$ \\
\hline $\begin{array}{c}\text { Reduced } \\
\text { glutathione } \\
\text { (mg/dl) }\end{array}$ & $51.31 \pm 1.87$ & $\begin{array}{c}2.22 \pm \\
0.59\end{array}$ & $\begin{array}{c}50.90 \pm \\
1.70\end{array}$ & $\begin{array}{c}3.83 \pm \\
0.64\end{array}$ & $\begin{array}{c}50.85 \pm \\
1.73\end{array}$ & $\begin{array}{c}7.87 \pm \\
0.74\end{array}$ \\
\hline $\begin{array}{c}\text { Superoxidase } \\
\text { dismutase }(\mathrm{U} / \mathrm{ml})\end{array}$ & $28.37 \pm 0.62$ & $\begin{array}{l}4.66 \pm \\
0.26\end{array}$ & $\begin{array}{c}28.47 \pm \\
0.62\end{array}$ & $\begin{array}{c}6.82 \pm \\
0.19\end{array}$ & $\begin{array}{c}28.42 \pm \\
0.58\end{array}$ & $\begin{array}{c}9.95 \pm \\
0.27\end{array}$ \\
\hline
\end{tabular}

Table (2): Effect of Emblica officinalis on serum parameters for TB mice at different periods after treatment.

\begin{tabular}{|c|c|c|c|c|}
\hline \multirow{2}{*}{ Parameters } & \multirow{2}{*}{$\begin{array}{c}\text { Period } \\
(\text { weeks })\end{array}$} & \multicolumn{3}{|c|}{ Emblica Officinalis, (mg) } \\
\cline { 2 - 5 } & 1 & $\mathbf{0 . 0}$ & 500 & 1250 \\
\hline \multirow{3}{*}{ ALT (U/ml) } & 2 & $348.33 \pm 17.21$ & $159.83 \pm 1.30$ & $156.50 \pm 1.23$ \\
\cline { 2 - 5 } & 3 & $531.17 \pm 17.30$ & $146.50 \pm 1.17$ & $137.83 \pm 2.15$ \\
\hline \multirow{3}{*}{ AST (U/ml) } & 1 & $211.27 \pm 5.85$ & $165.77 \pm 5.16$ & $125.03 \pm 4.82$ \\
\cline { 2 - 5 } & 2 & $264.67 \pm 4.60$ & $107.20 \pm 1.33$ & $\mathbf{8 8 . 5 3} \pm 2.45$ \\
\cline { 2 - 5 } & 3 & $354.77 \pm 12.58$ & $\mathbf{8 8 . 2 7} \pm 1.11$ & $66.40 \pm 3.18$ \\
\hline \multirow{2}{*}{ Bilirubin (mg/d) } & 1 & $2.58 \pm 0.03$ & $1.32 \pm 0.04$ & $1.05 \pm 0.02$ \\
\cline { 2 - 5 } & 2 & $2.30 \pm 0.04$ & $1.38 \pm 0.03$ & $1.27 \pm 0.02$ \\
\hline
\end{tabular}




\begin{tabular}{|c|c|c|c|c|}
\hline & 3 & $2.00 \pm 0.06$ & $1.63 \pm 0.03$ & $1.50 \pm 0.03$ \\
\hline \multirow{3}{*}{$\begin{array}{c}\text { Creatinine concentrtion } \\
\qquad(\mathrm{mg} / \mathrm{dl})\end{array}$} & 1 & $2.32 \pm 0.86$ & $2.10 \pm 0.38$ & $1.95 \pm 0.07$ \\
\hline & 2 & $2.78 \pm 0.28$ & $1.96 \pm 0.18$ & $1.68 \pm 0.13$ \\
\hline & 3 & $2.98 \pm 0.52$ & $1.72 \pm 0.76$ & $1.38 \pm 0.15$ \\
\hline \multirow{3}{*}{$\begin{array}{l}\text { Alkaline phosphatase } \\
\qquad(\mathrm{U} / \mathrm{ml})\end{array}$} & 1 & $58.98 \pm 0.76$ & $23.60 \pm 0.93$ & $19.67 \pm 0.66$ \\
\hline & 2 & $54.53 \pm 1.17$ & $27.93 \pm 0.50$ & $24.41 \pm 0.63$ \\
\hline & 3 & $47.86 \pm 2.59$ & $34.88 \pm 1.65$ & $29.10 \pm 0.72$ \\
\hline \multirow{3}{*}{$\begin{array}{l}\text { Catalase activity } \\
\qquad(\mathrm{nmol} / \mathrm{ml})\end{array}$} & 1 & $0.65 \pm 0.026$ & $0.79 \pm 0.015$ & $086 \pm 0.015$ \\
\hline & 2 & $0.44 \pm 0.008$ & $0.89 \pm 0.006$ & $0.95 \pm 0.01$ \\
\hline & 3 & $0.17 \pm 0.014$ & $1.12 \pm 0.097$ & $1.46 \pm 0.055$ \\
\hline \multirow{3}{*}{$\begin{array}{l}\text { Reduced glutathione } \\
\qquad(\mathbf{m g} / \mathbf{d l})\end{array}$} & 1 & $2.22 \pm 0.59$ & $25.08 \pm 0.47$ & $48.73 \pm 1.31$ \\
\hline & 2 & $3.83 \pm 0.64$ & $18.68 \pm 0.77$ & $35.83 \pm 1.31$ \\
\hline & 3 & $7.87 \pm 0.74$ & $13.58 \pm 0.63$ & $18.09 \pm 1.06$ \\
\hline \multirow{3}{*}{$\begin{array}{c}\text { Superoxidase } \\
\text { dismutase }(\mathrm{U} / \mathrm{ml})\end{array}$} & 1 & $4.66 \pm 0.26$ & $20.29 \pm 0.36$ & $23.02 \pm 0.25$ \\
\hline & 2 & $6.82 \pm 0.19$ & $15.69 \pm 0.23$ & $20.00 \pm 0.26$ \\
\hline & 3 & $9.95 \pm 0.27$ & $13.76 \pm 1.71$ & $34.19 \pm 6.67$ \\
\hline
\end{tabular}

Table (3): Effects of Emblica officinals (EO) on survival rate and percentage of TB- mice:

\begin{tabular}{|c|c|c|c|c|}
\hline Group & $\begin{array}{c}\text { Number of } \\
\text { Mice }\end{array}$ & $\begin{array}{c}\text { Number of } \\
\text { survived mice }\end{array}$ & $\begin{array}{c}\text { Number of } \\
\text { dead mice }\end{array}$ & $\begin{array}{c}\text { Percentage of } \\
\text { survival rate }\end{array}$ \\
\hline $0.00 \mathrm{mg} / \mathrm{kg} \mathrm{EO}$ & 30 & 18 & 12 & $60 \%$ \\
\hline $500 \mathrm{mg} / \mathrm{kg} \mathrm{EO}$ & 30 & 23 & 7 & $76.66 \%$ \\
\hline $1250 \mathrm{mg} / \mathrm{kg} \mathrm{EO}$ & 30 & 26 & 4 & $86.66 \%$ \\
\hline
\end{tabular}

Table (4): Effects of Emblica Officinals (EO) on volume of ascitic fluid and count of tumour cells per ml in T-bearing mice:

\begin{tabular}{|c|c|c|c|c|}
\hline Group & Traits & Day 8 & Day 15 & Day 23 \\
\hline \multirow{2}{*}{$0.00 \mathrm{mg} / \mathrm{kg}$ EO } & Volume & $6.67 \pm 0.65$ & $7.23 \pm 0.265$ & $14.76 \pm 0.78$ \\
\cline { 2 - 5 } & Cell count $(x \mathrm{106})$ & $128.25 \pm 13.87$ & $124.26 \pm 10.27$ & $120.85 \pm 20.45$ \\
\hline \multirow{2}{*}{$500 \mathrm{mg} / \mathrm{kg}$ EO } & Volume & $4.56^{*} \pm 0.21$ & $5.23 * \pm 0.44$ & $4.87^{*} \pm 0.29$ \\
\cline { 2 - 5 } & Cell count $(x 106)$ & $86.23 * \pm 11.79$ & $92.13 * \pm 13.56$ & $86.27^{*} \pm 17.56$ \\
\hline \multirow{2}{*}{$1250 \mathrm{mg} / \mathrm{kg}$} & Volume & $3.21 * \# \pm 0.24$ & $3.32 * \# \pm 0.43$ & $2.93 * \# \pm 0.27$ \\
\cline { 2 - 5 } EO & Cell count $(x 106)$ & $65.29 * \# \pm 12.97$ & $64.56^{*} \# \pm 15.23$ & $62.43 * \# \pm 14.92$ \\
\hline
\end{tabular}




\section{References}

1.Durairaj AK, Vaiyapuri ST, Mazumder U and Gupta M. Antineoplastic and antioxidant activities of Oxystelma esculentum on Swiss albino mice bearing Ehrlich's Ascites Carcinoma. Pharm Biol. 2009, 47:195-202.

2. Jha NK. Emblica officnalis Indian gooseberry. Amla. Phytopharm. 200, 8:3-25

3. Jain S, Gill V, Vasudeva N and Singla N. Ayurvedic medicines in treatment of cancer. J. Chinese integrative med., 2003, 7:1096-9.

4. Nandi P, Talukderl G and Sharma A. Dietary chemoprevention of clastogenic effects of 3,4- benzo(a)pyrene by Emblica officinalis Gaertn Fruit extract. Br J Cancer; 1997, 76: $1279-83$.

5. Reitman S and Frankel S. A calorimetric method for the determination of serum GOT and GPT. American J. of Clin. Pathology, 1957, 28:56-63.

6. Walter $M$ and Gerarde $H$. Ultramicromethod for the determination of conjugated and total bilirubin in serum or plasma. Microchemistry Journal, 1970, 15:231-36.

7. Rock RC, Walker WG and Jennings CD. Nitrogen metabolites and renal function. In: Tietz NW, ed. Fundamentals of clinical chemistry. 3rd ed. Philadellphia: WB Saunders. 1987, 669-704. 8. Aebi H. Methods Enzymol 1984, 105: 121 - 126.

9. Bozzi A, Mavelli J, Finazzi Agro A, Strom R, Wolf A M, Mondovi B and Rotilio.G. Enzyme defense against reactive oxygen derivativesII Erythrocytes. and tumour cells mol.cell Biochem. 1976, 11-16.

10. Nishikimi M, Roa NA and Yogi K. Biochem. Bioph. Res. Common., 1972, 46: $849-854$.

11. SAS Institute (2004). SAS User's Guide: Statistics. Edition 9.1. SAS Institute Inc., Cary, NC.

12. Duncan DB. Multiple range and multiple $F$ tests. Biometrics, 1955, 11:1-42.

13. Rafei I, Fawzeya MA and Mohammed B. Possible renal dysfunction effect of nigella sativa seeds in rabbits. J. Biochem Sci. Therapeutic 1993, 9: 19-25.

14. Salem FS, Badr MO, Neamat-Allah AN. Biochemical and pathological studies on the effects of levamisole and chlorambucil on Ehrlich ascites carcinoma bearing mice. Vet Italiana, 2001, 47(1):89-95

15. Tofani S, Cintorino M, Barone D, Berardelli M, De Santi, Ferrera A, Orlassino R, Ossola P, Rolfo K, Ronchetto F, Tripodi SA and Tosi P. Increased mouse survival, tumor growth inhibition and decreased immunoreactive p53 after exposure to magnetic fields. Bioelectromagnetics, 2002, 23 (3), 230-238.

16. Chen TS, Liou SY and Chang YL. Supplementation of Emblica Officinalis (Amla) extract reduces oxidative stress in uremic patients. Am. J. Chin Med.,2009, 37:19-25.

17. Tasduq SA, Kaisar P, Gupta D, Kapahi BH, Maheshwari SH and Jyotsna S. Protective effect of a $50 \%$ hydroalcoholic fruit extract of Emblica Officinalis against anti-tuberculosis drugs induced liver toxicity. Phytother Res. 2005,19:193-197. 18. Abd El-Salam IM, Abdel-Wahab S, El-aeser A and ElMerazabani M. Biochemical and cytotoxic effectof nigella sativa 1. Egypt. J. biochem., 1992, 10(2):348-355.

19. Leema, AV. (2011). Evaluation of the three anticancer activity of three Important ayurvedic medicine plants in transplantable tumor bearing mice. M. Pharm. Dissertation, 2011, 5: 254-259.

20. Thorat SP, Rege NN, Naik AS, Thatte UM, Joshi UM and Panicker DN. Emblica officinalis:A Novel Therapy for Acute Pancreatitis An Experimental Study HPB Surgery 1995, 9:2530.

21. Hussein SA. (2003). Clinical biochemistry interpretation and applications First Edition (Text Book).

22. Kawaguchi H, Itoh K, Mori H, Hayashi Y and Makino S. Renal Pathology in rats bearing tumor-secreting growth hormones. Pediatrnephrol, 1991, 5 (4): 533-8.
23. Prasad SB and Giri A. Antitumore effect of Cisplatin against murie ascites Dalton's Lymphoma. Indian J. Exp. Biol.1994, 32:155.

24. Stefan LM, Westman NG, Lundgren E and Roos G. Copper-and Zinc-containing Superoxide Dismutase, Manganese-containing Superoxide Dismutase, Catalase, and Glutathione Peroxidase in Normal and Neoplastic Human Cell Lines and Normal Human Tissues .Cancer Res., 1997, 42, 1955-1961. 